\title{
The impact of statin therapy on long-term cardiovascular outcomes in an outpatient cardiology practice
}

Hoang M. Lai ${ }^{1}$, Wilbert S. Aronow ${ }^{1}$, Anthony D. Mercando ${ }^{1}$, Phoenix Kalen ${ }^{2}$, Harit V. Desai ${ }^{1}$, Kaushang Gandhi', Mala Sharma ${ }^{1}$, Harshad Amin ${ }^{1}$, Trung M. Lai ${ }^{1}$

1Department of Medicine, New York Medical College, Valhalla, NY, USA 2Westchester Cardiology Associates/WestMed Medical Group and Department of Medicine, Columbia University College of Physicians and Surgeons, New York, USA

Submitted: 7 October 2011

Accepted: 7 November 2011

Arch Med Sci 2012; 8, 1: 53-56

DOI: $10.5114 /$ aoms.2012.27281

Copyright $\odot 2012$ Termedia \& Banach

\section{Abstract}

Introduction: Statins reduce coronary events in patients with coronary artery disease.

Material and methods: Chart reviews were performed in 305 patients (217 men and 88 women, mean age 74 years) not treated with statins during the first year of being seen in an outpatient cardiology practice but subsequently treated with statins. Based on the starting date of statins use, the long-term outcomes of myocardial infarction (MI), percutaneous coronary intervention ( $\mathrm{PCI}$ ), and coronary artery bypass graft surgery (CABGs) before and after statin use were compared.

Results: Mean follow-up was 65 months before statins use and 66 months after statins use. Myocardial infarction occurred in 31 of 305 patients (10\%) before statins, and in 13 of 305 patients $(4 \%)$ after statins $(p<0.01)$. Percutaneous coronary intervention had been performed in 66 of 305 patients (22\%) before statins and was performed in 41 of 305 patients $(13 \%)$ after statins $(p<0.01)$. Coronary artery bypass graft surgery had been performed in 56 of 305 patients $(18 \%)$ before statins and in 20 of 305 patients $(7 \%)$ after statins $(p<0.001)$. Stepwise logistic regression showed statins use was an independent risk factor for $\mathrm{MI}$ (odds ratio $=0.0207,95 \% \mathrm{Cl}, 0.0082-0.0522, p<0.0001$ ), $\mathrm{PCl}$ (odds ratio $=0.0109,95 \% \mathrm{Cl}, 0.0038-0.0315, p<0.0001$ ) and CABGs (odds ratio $=$ $0.0177,95 \% \mathrm{Cl}=0.0072-0.0431, p<0.0001)$

Conclusions: Statins use in an outpatient cardiology practice reduces the incidence of $\mathrm{MI}, \mathrm{PCl}$, and CABGs.

Key words: statins, myocardial infarction, coronary revascularization.

\section{Introduction}

Numerous studies have demonstrated that statins reduce the incidence of coronary events in patients at high risk for coronary events [1-8]. The efficacy of statins in reducing coronary events in an outpatient cardiology practice needed to be investigated. This article reports data comparing the incidence of new myocardial infarction (MI), of new percutaneous coronary intervention $(\mathrm{PCI})$, and of new coronary artery bypass graft surgery (CABGs) in 305 patients, mean age 74 years (93\% with coronary artery disease), treated in an academic community cardiology practice during the

\author{
Corresponding author: \\ Wilbert S. Aronow MD \\ Cardiology Division \\ New York Medical College \\ Macy Pavilion, Room 138 \\ Valhalla, New York, USA \\ Phone: (914) 493-5311 \\ Fax: (914) 235-6274 \\ E-mail: wsaronow@aol.com
}


time they were not treated with statins vs. during the time they were subsequently treated with statins.

\section{Material and methods}

Paper and electronics chart reviews were used to screen patients treated with statins at an academic community cardiology practice from 1978 to 2008. Based on the starting date of statin use, longterm clinical outcomes before and after statins start dates were calculated and compared. Patients who were treated with statins within the first year of follow-up were excluded from the study in order to achieve comparable duration of follow-up. Out of 1 , 599 patients screened at the practice [9], 305 patients met all criteria and were included in the study.

For every patient, progress notes of all interim visits, letters of correspondence, medication use, blood pressure, laboratory studies including serum lipid levels, and occurrence of adverse cardiovascular events from the time of initial presentation to the last follow-up were recorded. Adverse events included occurrence of $\mathrm{MI}$, need for $\mathrm{PCl}$, and need for CABGs. Drug therapy and patient comorbidities including coronary artery disease, hyperlipidemia, hypertension, diabetes mellitus, cigarette smoking history,

Table I. Baseline characteristics of 305 patients

\begin{tabular}{|c|c|}
\hline Age [years] & $74 \pm 10$ \\
\hline Men & 217 \\
\hline Women & 88 \\
\hline Follow-up before statin use [months] & 65 \\
\hline Follow-up after statin use [months] & 64 \\
\hline Coronary artery disease & $283(93 \%)$ \\
\hline Hyperlipidemia & $270(89 \%)$ \\
\hline Hypertension & $251(82 \%)$ \\
\hline Diabetes mellitus & $76(25 \%)$ \\
\hline Congestive heart failure & $49(16 \%)$ \\
\hline Angina pectoris & $35(11 \%)$ \\
\hline Atrial fibrillation & $54(18 \%)$ \\
\hline Carotid artery stenosis & $18(6 \%)$ \\
\hline Stroke & $30(10 \%)$ \\
\hline Transient ischemic attack & $18(6 \%)$ \\
\hline Chronic renal disease & $8(3 \%)$ \\
\hline Peripheral arterial disease & $35(11 \%)$ \\
\hline Abdominal aortic aneurysm & $12(4 \%)$ \\
\hline Smoker & $130(43 \%)$ \\
\hline Prior myocardial infarction & $102(33 \%)$ \\
\hline Prior percutaneous coronary intervention & $49(16 \%)$ \\
\hline Prior coronary artery bypass graft surgery & $49(16 \%)$ \\
\hline
\end{tabular}

congestive heart failure, angina, atrial fibrillation, chronic kidney disease, peripheral arterial disease, abdominal aortic aneurysm, carotid artery stenosis, transient ischemic attack, stroke, and previous $\mathrm{MI}$, $\mathrm{PCl}$, and CABGS were recorded. Dates of the events as well as dates of medication initiation and discontinuation were recorded. Coronary artery disease was diagnosed as previously described [10-16].

Data were extracted by the physician authors and tabulated with Microsoft Access 2003 (Microsoft Corporation, Redmond, WA, USA). Customized computer programming was written for macros within Microsoft Excel 2003. The McNemar test was used to compare clinical outcomes. Adverse events occurring before the time of initial presentation were not included in the outcomes analysis. Stepwise logistic regression was performed with MEDCAL statistical software using the 48 variables listed in Tables I and II to determine if use of statins was independently associated with $\mathrm{MI}, \mathrm{PCl}$, and CABGS. A two-sided $p$ value of $<0.05$ was considered significant.

\section{Results}

Table I shows the baseline characteristics of the 305 patients. Table II shows the prevalence of use of drugs in the 305 patients before, after, and before and after use of statins. Table III shows the mean blood pressure and serum lipids levels before and after use of statins. Table III also shows levels of statistical significance. Table IV shows the incidence of $\mathrm{MI}$, of $\mathrm{PCl}$, and of CABGs before and after treatment with statins. Table III also shows levels of statistical significance.

Stepwise logistic regression analysis showed that use of statins was a significant independent predictor of new MI (odds ratio $=0.0207 ; 95 \% \mathrm{Cl}$ 0.0082-0.0522; $p<0.0001$ ), of new PCl (odds ratio $=0.0109 ; 95 \% \mathrm{Cl} 0.0038-0.0315 ; p<0.0001)$ and of new CABGs (odds ratio $=0.0177 ; 95 \% \mathrm{Cl} 0.0072$ $0.0431 ; p<0.0001)$.

\section{Discussion}

Numerous studies have demonstrated that statins reduce the incidence of coronary events in patients at high risk for coronary events [1-8]. The present study compared the incidence of new MI, of new $\mathrm{PCl}$, and of new CABGs in 305 patients, mean age 74 years ( $93 \%$ with coronary artery disease), treated in an academic community cardiology practice during the time they were not treated with statins versus during the time they were subsequently treated with statins.

At 65-month follow-up before treatment with statins and at 64-month follow-up after treatment with statins, the incidence of new MI was significantly reduced from $10 \%$ to $4 \%$ by statins ( $p<0.01$ ), 
Table II. Drug therapy in 305 patients

\begin{tabular}{|lcc|}
\hline Medications & Number (\%) & $\begin{array}{c}\text { Mean duration } \\
\text { of therapy [years] }\end{array}$ \\
\hline Statins & $305(100)$ & 5.36 \\
\hline Ezetimibe & $78(26)$ & 2.12 \\
\hline Niacin & $26(9)$ & 2.49 \\
\hline Bile acid sequestrants & $7(2)$ & 1.12 \\
\hline Fibrates & $34(11)$ & 3.42 \\
\hline Fish oils & $14(5)$ & 1.94 \\
\hline$\beta$-Blockers & $260(85)$ & 8.06 \\
\hline Diuretics & $180(59)$ & 5.72 \\
\hline $\begin{array}{l}\text { Angiotensin-converting } \\
\text { enzyme inhibitors }\end{array}$ & $225(74)$ & 5.38 \\
\hline $\begin{array}{l}\text { Angiotensin receptor } \\
\text { blockers }\end{array}$ & $102(33)$ & 3.76 \\
\hline $\begin{array}{l}\text { Calcium channel } \\
\text { blockers }\end{array}$ & $187(61)$ & 6.29 \\
\hline Other antihypertensives & $32(10)$ & 4.73 \\
\hline Aspirin & $270(89)$ & 8.41 \\
\hline Ticlopidine & $10(3)$ & 3.18 \\
\hline Clopidogrel & $82(27)$ & 2.19 \\
\hline $\begin{array}{l}\text { Aspirin/ } \\
\text { extended-release } \\
\text { dipyridamole }\end{array}$ & $2(1)$ & 3.34 \\
\hline Other antiplatelet drugs & $6(2)$ & 2.9 .64 \\
\hline Warfarin & $100(33)$ & 4.90 \\
\hline Nitrates & $116(38)$ & 5.26 \\
\hline Digoxin & $70(23)$ & 5.34 \\
\hline Cilostazol & 2.65 \\
\hline Insulin & 8.60 \\
\hline Thiazolidinediones & $35)$ \\
\hline Sulfonylureas & \\
\hline Metformin & \\
\hline Sitagliptin & \\
\hline
\end{tabular}

the incidence of new $\mathrm{PCl}$ was significantly reduced from $22 \%$ to $13 \%$ by statins $(p<0.01$ ), and the incidence of new CABGs was significantly reduced from $18 \%$ to $7 \%$ by statins $(p<0.001)$. Stepwise logistic regression analysis using 48 variables showed that use of statins was a significant independent risk factor for reducing new $\mathrm{MI}$, new $\mathrm{PCl}$ and new CABGs $(p<0.0001)$.

Our data show that use of statins in patients with overt coronary artery disease (93\%) or at highrisk for coronary artery disease in a community cardiology practice can reduce their chance of developing new $\mathrm{MI}$, new $\mathrm{PCl}$ and new CABGs. This study should give community practitioners, both specialists and primary care providers, the encouragement
Table III. Blood pressure and serum lipid levels before and after statin therapy

\begin{tabular}{|c|c|c|c|}
\hline Variable & $\begin{array}{l}\text { Before } \\
\text { statins }\end{array}$ & $\begin{array}{l}\text { After } \\
\text { statins }\end{array}$ & Value of $p$ \\
\hline $\begin{array}{l}\text { Systolic blood } \\
\text { pressure }[\mathrm{mmHg}]\end{array}$ & $134 \pm 14$ & $130 \pm 13$ & $<0.01$ \\
\hline $\begin{array}{l}\text { Diastolic blood } \\
\text { pressure }[\mathrm{mmHg}]\end{array}$ & $78 \pm 8$ & $73 \pm 7$ & $<0.001$ \\
\hline $\begin{array}{l}\text { Mean arterial } \\
\text { pressure }[\mathrm{mmHg}]\end{array}$ & $97 \pm 9$ & $92 \pm 8$ & $<0.001$ \\
\hline Total cholesterol & $195 \pm 43$ & $157 \pm 32$ & $<0.001$ \\
\hline $\begin{array}{l}\text { LDL cholesterol } \\
{[\mathrm{mg} / \mathrm{dl}]}\end{array}$ & $118 \pm 38$ & $80 \pm 22$ & $<0.001$ \\
\hline $\begin{array}{l}\text { HDL cholesterol } \\
{[\mathrm{mg} / \mathrm{dl}]}\end{array}$ & $45 \pm 13$ & $49 \pm 15$ & $<0.01$ \\
\hline $\begin{array}{l}\text { Triglycerides } \\
{[\mathrm{mg} / \mathrm{dl}]}\end{array}$ & $168 \pm 96$ & $147 \pm 82$ & $<0.05$ \\
\hline
\end{tabular}

$L D L$ - low-density lipoprotein, $H D L$ - high-density lipoprotein

Table IV. Incidence of myocardial infarction and coronary revascularization before and after use of statins

\begin{tabular}{|lccc|}
\hline & $\begin{array}{c}\text { Before } \\
\text { statins }\end{array}$ & $\begin{array}{c}\text { After } \\
\text { statins }\end{array}$ & Value of $p$ \\
\hline Myocardial infarction & $31(10 \%)$ & $13(4 \%)$ & $<0.01$ \\
\hline $\begin{array}{l}\text { Percutaneous coronary } \\
\text { intervention }\end{array}$ & $66(22 \%)$ & $41(13 \%)$ & $<0.01$ \\
\hline $\begin{array}{l}\text { Coronary artery bypass } \\
\text { graft surgery }\end{array}$ & $56(18 \%)$ & $20(7 \%)$ & $<0.001$ \\
\hline
\end{tabular}

to pursue cardiovascular risk reduction strategies as a means for reducing new $\mathrm{MI}, \mathrm{PCl}$ and CABGs in their patients.

A limitation of this study is that it is a retrospective chart analysis study with all inherent problems of such a design.

\section{Acknowledgments}

The authors thank the members of Westchester Cardiology Associates in Scarsdale, New York who do not appear as authors in this paper: Stanley Epstein MD, Mitchell Fishbach MD, Gary Gabelman MD, Richard Grose MD, Douglas Hart MD, and Gabriela Grasa MD. Their superb care provided the benefits to their patients cited in this paper.

None of the authors have any conflicts of interest. The study was performed without any outside financial support.

This study was presented at the Annual Scientific Meeting of The American College of Cardiology in New Orleans, Louisiana in April, 2011.

\section{References}

1. Miettinen TA, Pyörälä K, Olsson AG, et al. Cholesterollowering therapy in women and elderly patients with 
myocardial infarction or angina pectoris: findings from the Scandinavian Simvastatin Survival Study (4S). Circulation 1997; 96: 4211-8.

2. Lewis SJ, Moye LA, Sacks FM, et al. Effect of pravastatin on cardiovascular events in older patients with myocardial infarction and cholesterol levels in the average range. Results of the Cholesterol and Recurrent Events (CARE) Trial. Ann Intern Med 1998; 129: 681-9.

3. The Long-Term Intervention with Pravastatin in Ischaemic Disease (LIPID) Study Group. Prevention of cardiovascular events and death with pravastatin in patients with coronary heart disease and a broad range of initial cholesterol levels. N Engl J Med 1998; 339: 1349-57.

4. Heart Protection Study Collaborative Group. MRC/BHF Heart Protection Study of cholesterol lowering with simvastatin in 20,536 high-risk individuals: a randomised placebo-controlled trial. Lancet 2002; 360: 7-22.

5. Cannon $\mathrm{CP}$, Braunwald $\mathrm{E}, \mathrm{McC}$ abe $\mathrm{CH}$, et al. Intensive versus moderate lipid lowering with statins after acute coronary syndromes. N Engl J Med 2004; 350: 1495-504.

6. LaRosa JC, Grundy SM, Waters DD, et al. Intensive lipid lowering with atorvastatin in patients with stable coronary disease. N Eng J Med 2005; 352: 1425-35.

7. Aronow WS, Ahn C. Incidence of new coronary events in older persons with prior myocardial infarction and serum low-density lipoprotein cholesterol $\geq 125 \mathrm{mg} / \mathrm{dl}$ treated with statins versus no lipid-lowering drug. Am J Cardiol 2002; 89: 67-9.

8. Szadkowska I, Stanczyk A, Aronow WS, et al. Statin therapy in the elderly: a review. Arch Gerontol Geriatr 2010; 50: 114-8.

9. Mercando AD, Lai HM, Aronow WS, et al. Reduction in atherosclerotic events: a retrospective study in an outpatient cardiology practice. Arch Med Sci 2012; 8: 59-64.

10. Lai HM, Aronow WS, Rachdev A, et al. Incidence of mortality in 1,040 patients with coronary heart disease or hypertensive heart disease with normal and abnormal left ventricular ejection fraction and with normal and abnormal QRS duration. Arch Med Sci 2008; 4: 140-2.

11. Ramdeen N, Aronow WS, Chugh S, Asija A. Patients undergoing coronary angiography because of chest pain with hepatitis $C$ virus have a higher prevalence of obstructive coronary artery disease than a control group. Arch Med Sci 2008; 4: 452-4.

12. Kannam H, Aronow WS, Chilappa K, et al. Association of the QRS duration on the resting electrocardiogram with the severity of coronary artery disease in 2,196 patients undergoing coronary angiography for suspected coronary artery disease. Arch Med Sci 2009; 5: 163-5.

13. Shao JH, Aronow WS, Ravipati G, et al. Prevalence of a minimal luminal cross sectional area of coronary arteries $<4 \mathrm{~mm}^{2}$ determined by intravascular ultrasound in patients with coronary artery calcium scores of 0-100, 100-200, 200-300, 300-400, and > 400 determined by cardiac computer tomography. Arch Med Sci 2009; 5: 172-4.

14. Shen $X$, Aronow WS, Nair CK, et al. Thoracic aortic atheroma severity predicts high-risk coronary anatomy in patients undergoing transesophageal echocardiography. Arch Med Sci 2011; 7: 61-6.

15. Aronow WS. Osteoporosis, osteopenia, and atherosclerotic vascular disease. Arch Med Sci 2011; 7: 21-6.

16. Duncan KA, Sukhija R, Aronow WS, et al. Systolic compression of left main coronary artery by left ventricular pseudoaneurysm complicated by critical stenosis. Arch Med Sci 2012; 8 (in press). 